\title{
EFFECT OF LONG-TERM AGING ON SERIES RESISTANCE AND JUNCTION CONDUCTIVITY OF HIGH-POWER InGaN LIGHT-EMITTING DIODES
}

\author{
Z. Vaitonis, A. Miasojedovas, A. Novičkovas, S. Sakalauskas, and A. Žukauskas \\ Institute of Materials Science and Applied Research, Vilnius University, Sauletekio 9, LT-10222 Vilnius, Lithuania \\ E-mail: zenonas.vaitonis@ff.vu.lt
}

Received 12 December 2008; revised 13 March 2009; accepted 19 March 2009

\begin{abstract}
The forward voltage, series resistance, and junction conductivity of commercial high-power InGaN light-emitting diodes (LEDs) were investigated as a function of aging time. A gradual decrease of series resistance with a rate of about $-1 \% / 1000 \mathrm{~h}$ was revealed in InGaN LEDs within first $~ 9,600$ hours of aging under ordinary conditions (nominal forward current $350 \mathrm{~mA}$, junction temperature $350 \mathrm{~K}$ ), whereas the characteristic energy of tunnel injection exhibited a decrease with a rate of about $-0.1 \% / 1000 \mathrm{~h}$. The observed aging effects were attributed to continuous post-fabrication self-annealing of the $p$-type cladding layer and to the variation of the localized-state density in the active layer of the LED chips.
\end{abstract}

Keywords: aging, high-power LED, series resistance, junction conductivity

PACS: $81.40 . \mathrm{Cd}, 85.60 . \mathrm{Bt}, 85.60 . \mathrm{Jb}, 84.37 .+\mathrm{q}, 73.40 . \mathrm{Kp}$

\section{Introduction}

LEDs are new-generation lighting devices with a potential of higher efficiency and quality of light and unsurpassed longevity [1]. Commercial high-power InGaN and AlInGaP LEDs already exhibit operational time in excess of 50,000 hours at 70\% lumen maintenance. To this end, long-term variation of the optical and electrical characteristics of LEDs is of crucial interest for the further promotion of solid-state lighting technology. Degradation of the output flux of LEDs received a lot of attention [2-5], although the background physical and materials' issues still require deeper understanding. Meanwhile, the effects of aging on electrical characteristics of LEDs are usually categorized as follows [6-10]: (i) an increase of sub-onset forward current due to an occurrence of additional nonradiative recombination routes, (ii) an increase of reverse current, and (iii) a decrease of forward current at nominal voltages mainly due to the deterioration of electrodes and contact layers. An increase of forward current in the entire range of voltages in aged InGaN LEDs was also observed and attributed to an occurrence of dislocationrelated ohmic shorts within the chip [11].

For practical purposes, e.g. for designing power supplies projected for $\sim 50,000-100,000$ hours of operation, long-term variation of electrical characteristics that condition the forward voltage of LEDs is to be addressed in more detail. Here we report on the effect of long-term aging in the nominal-current regime on the forward voltage of commercial high-power InGaN LEDs and analyse this effect in terms of variation of series resistance and junction conductivity.

\section{Experiment}

Blue 1-W InGaN flip-chip LEDs (Philips Lumileds Lighting model LXHL-MRRD) $[12,13]$ with the emission peak wavelength around $444 \mathrm{~nm}$ were investigated. The chip of the LEDs (die size $1 \times 1 \times 0.1 \mathrm{~mm}^{3}$ ) consisted of a sapphire substrate and a thin semiconductor structure. The aging cycles were carried out at the nominal dc current of $350 \mathrm{~mA}\left(\sim 60 \mathrm{~A} / \mathrm{cm}^{2}\right)$ with the LEDs mounted on a heat sink that was kept at the ambient temperature of $293 \pm 3 \mathrm{~K}$ (the junction temperature was higher, as indicated below). A series of 4 identical LEDs was investigated. During the aging, the LEDs exhibited individual variation of the output flux, which was in line with the rated average lumen maintenance characteristics [13], but poorly correlated with the variation of electrical characteristics described below. Meanwhile, we found no noticeable variation of 
the shape and peak position of the electroluminescence spectra during the aging process.

Series resistance and junction conductivity were evaluated from current-voltage $(I-V)$ characteristics, measured at relatively high forward currents in the range of $1 \mathrm{~mA}<I_{\mathrm{F}}<400 \mathrm{~mA}$ (for lower currents, the accuracy of the measurement was limited by the ESD protection circuit built in the silicon submount, which consumed current of less than $10 \mu \mathrm{A}$ in both virgin and aged LEDs). To avoid ambiguities caused by self-heating of the junction, the $I-V$ characteristics were recorded in the pulsed mode (pulse duration $300 \mu$ s, duty cycle $0.3 \%$ ) using a pulsed source meter (Keithley model 2430). During the measurement, the LEDs were mounted within an evacuated optical cryostat / oven (Cryo Industries model 110-637-DND). The temperature of the mount was maintained at $298 \mathrm{~K}$ with an accuracy better than $0.1 \mathrm{~K}$. The overall uncertainty of the chip temperature in the $I-V$ measurement estimated based on heat capacitance of sapphire was less than $1 \mathrm{~K}$. However, the analysis of the high-energy wing of the electroluminescence spectra has indicated that an additional increase in junction temperature of up to $4 \mathrm{~K}$ is possible [14]. For the temperature coefficient of the forward voltage of $-2 \mathrm{mV} / \mathrm{K}$ [13], this corresponds to the uncertainty of the forward voltage below $8 \mathrm{mV}$ within the used range of the forward current and below $0.16 \mathrm{mV}$ for the nominal current applied at different aging times (with the hereinafter estimated 2\% drop of forward voltage due to aging and a corresponding reduction of Joule's heat taken into account).

To avoid ambiguities due to short-term aging effects, the start-point measurements were performed after 500 hours of seasoning at the nominal conditions [15]. The measurements were repeated after subsequent aging for 2,500, 6,400, and 9,600 hours.

The same experimental arrangement was used for the calibration of the forward voltage method [16] for the estimation of the junction temperature during the aging cycles. Typical values of the junction temperature during the aging cycles were $350 \pm 5 \mathrm{~K}$ and were consistent with the rated thermal resistance of $20 \mathrm{~K} / \mathrm{W}$ [13].

\section{Results and discussion}

Figure 1(a) shows typical $I-V$ characteristics of an LED measured just after seasoning and after 9,600 hours of aging. Aging is seen to result in a marginal variation of the $I-V$ behaviour at sub-onset currents $\left(\delta V_{\mathrm{F}} \sim\right.$ $-5 \mathrm{mV}$ at $I_{\mathrm{F}}=1 \mathrm{~mA}$ ), which is probably due to the enhancement of nonradiative recombination and the emergence of ohmic shorts within the chip [6-11]. At the nominal current $(350 \mathrm{~mA})$, a remarkable drop in forward voltage $\left(\delta V_{\mathrm{F}}=-70 \mathrm{mV}\right)$ is observed. This drop can be attributed neither to nonradiative recombination, which tends to saturate at high forward currents, nor to shunt currents, which are expected to be linear with voltage.

The observed variation of the $I-V$ characteristics was analysed within a generalized Shockley equation with exponential contributions of diffusion, recombination, and tunnel injection mechanisms peculiar to InGaN LEDs [17-19]:

$$
I_{\mathrm{F}}=\sum_{i} I_{0 i}\left\{\exp \left[\frac{V_{\mathrm{F}}-I_{\mathrm{F}} R_{\mathrm{S}}}{E_{i} / q}\right]-1\right\} .
$$

Here, $I_{0 i}$ and $E_{i}$ are the reverse saturation current and the energy parameter of the $i$ th injection process, respectively, and $R_{\mathrm{S}}$ is the series resistance. For diffusion and recombination currents, the net energy parameter is $\eta_{\text {ideal }} k_{\mathrm{B}} T_{\mathrm{J}}$, with the ideality factor $1 \leq \eta_{\text {ideal }} \leq 2$ and junction temperature $T_{\mathrm{J}}$, whereas for tunnelling injection, the energy parameter is almost temperature independent. Provided that the injection current is dominated by a single component on the right-hand side of Eq. (1) and $I_{\mathrm{F}} \gg I_{0}$, differentiation by forward current yields the dynamic resistance

$$
R_{\mathrm{D}} \equiv \frac{\mathrm{d} V_{\mathrm{F}}}{\mathrm{d} I_{\mathrm{F}}}=R_{\mathrm{S}}+\frac{E_{0}}{q I_{\mathrm{F}}} .
$$

The second term on the right-hand side of Eq. (2) is the inverse junction conductivity, which for a particular forward current is determined solely by the energy parameter of the injection process. To distinguish between the components of the dynamic resistance, the differential $I-V$ characteristic, which is obtained from Eq. (2), can be used [20]:

$$
I_{\mathrm{F}} R_{\mathrm{D}} \equiv I_{\mathrm{F}} \frac{\mathrm{d} V_{\mathrm{F}}}{\mathrm{d} I_{\mathrm{F}}}=I_{\mathrm{F}} R_{\mathrm{S}}+\frac{E_{0}}{q} .
$$

By plotting the product $I_{\mathrm{F}} R_{\mathrm{D}}$ as a function of forward current, both the series resistance (the slope) and the characteristic injection energy (the extrapolated value at $\left.I_{\mathrm{F}}=0\right)$ can be extracted.

Figure 1(b) shows the differential $I-V$ characteristics of a just seasoned and long-term aged LED (data is derived from Fig. 1(a)). At high currents $\left(I_{\mathrm{F}}>\right.$ $100 \mathrm{~mA}$ ), the characteristics are seen to contain a linear part that indicates that an approximation by a single injection mechanism is applicable here. The slope yields the values of series resistance equal to $1.032 \pm 0.025 \Omega$ and $0.938 \pm 0.025 \Omega$ for the just seasoned and 9,600-h 

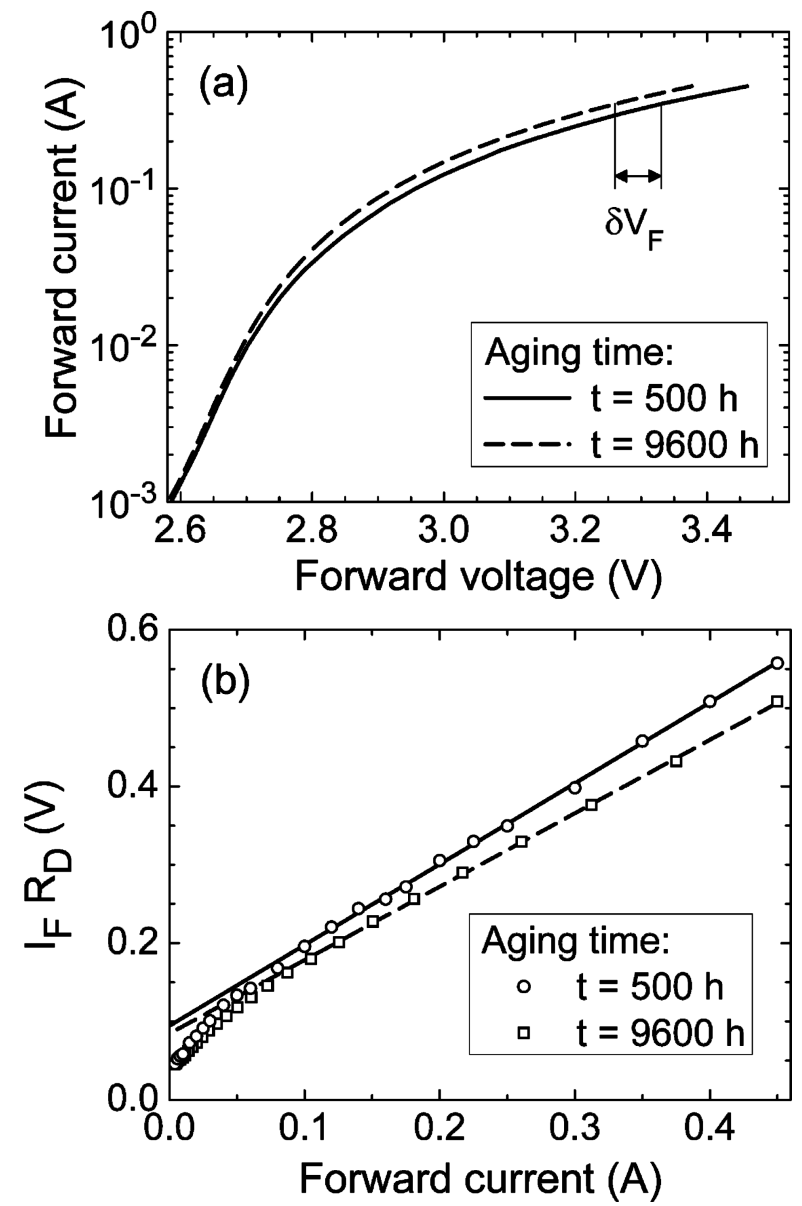

Fig. 1. (a) Semilogarithmic and (b) differential $I-V$ characteristics of a high-power InGaN LED just after 500-h seasoning (solid lines, circles) and 9,600-h aging (dashed lines, squares).

aged LED, respectively. Meanwhile, the intersection of the extrapolated linear parts with the vertical axis measures the energy parameter of the dominant injection mechanism $E_{0}$ that is equal to $94 \pm 5 \mathrm{meV}$ and $85 \pm 5 \mathrm{meV}$ for the just seasoned and aged LED, respectively. (The absolute errors for the values of the series resistance and energy parameter are determined by the method of least-squares used for the fitting of the experimental data to linear dependences.) The estimated values of the characteristic energy imply the values of the ideality factor are well above 2 , which indicate the domination of injection due to tunnelling $[17,18]$.

Differently from the series resistance, the above approach is seen to reveal no change in the energy parameter within the accuracy of the experiment. Therefore, we applied a more precise differential approach based on the variation of the forward voltage and the estimated variation of the series resistance. The variation of the forward voltage for an $I-V$ characteristic with one dominant injection mechanism is

$$
\delta V_{\mathrm{F}}=I_{\mathrm{F}} \delta R_{\mathrm{S}}+\left(V_{\mathrm{F}}-I_{\mathrm{F}} R_{\mathrm{S}}\right) \frac{\delta E_{0}}{E_{0}}-E_{0} \frac{\delta I_{0}}{q I_{0}} .
$$

For the values of parameters $\delta V_{\mathrm{F}}=-70 \mathrm{mV}$ (Fig. 1(a)), $\delta R_{\mathrm{S}}=-0.092 \pm 0.035 \Omega$, and $E_{0} \approx 90 \mathrm{mV}$, Eq. (4) yields $\delta E_{0}=-1.2 \pm 0.4 \mathrm{meV}$ (the third term on the right-hand side was neglected based on the analysis of the $I-V$ characteristics in the low-current regime). Now, the relative error for the variation of the characteristic energy is much smaller and almost equals the relative error for the variation of the series resistance.

Figure 2 displays the cumulative results of the effect of aging on electrical parameters of high-power InGaN LEDs at the nominal current. Figure 2(a) shows the average variation of the forward voltage with aging time for the 4 LEDs examined (the line corresponds to $-6.7 \mathrm{mV} / 1000 \mathrm{~h}$ or $-0.2 \% / 1000 \mathrm{~h}$ decrease rate). Figure 2(b) shows the average variation of the series resistance $(\sim-0.011 \Omega / 1000 \mathrm{~h}$ or $-1.1 \% / 1000 \mathrm{~h})$. The average variation of the characteristic energy of tunnelling injection is shown in Fig. 2(c) $(\sim-0.1 \mathrm{mV} / 1000 \mathrm{~h}$ or $-0.09 \% / 1000 \mathrm{~h}$ ). (For individual LEDs, the variations of the electrical parameters were dispersed within $10 \%$ of magnitude.) Such rates can be quite significant for the designing of driving electronics for LEDs with a long operation time. In particular, a 10\% drop of forward voltage can be anticipated for 50,000 hours of operation of the high-power InGaN LEDs investigated.

Our results are in line with the invoked decrease of forward voltage caused by short-term aging of InGaN LEDs reported in [21]. However, a detailed analysis revealed at least two comparable contributions to this effect, a decrease in series resistance and a decrease in characteristic tunnelling energy. The decrease in series resistance could be attributed to continuous annealing of the $p$ cladding layer in the light-emitting structure. Such a post-fabrication self-annealing can result in a higher density of holes due to the instability of residual $\mathrm{Mg}-\mathrm{H}$ complexes [21-23] and might be more pronounced in high-power LEDs operating at increased junction temperatures. However, the junction temperature of $350 \mathrm{~K}$ is too low to invoke conventional breakdown of the $\mathrm{Mg}-\mathrm{H}$ complexes, which are known to dissociate at about $1000 \mathrm{~K}$ [24]. On the other hand, in forward-biased diodes, minority-carrierenhanced debonding of hydrogen is known to facilitate annealing at much lower temperatures [25, 26]. For instance, a noticeable increase in hole concentration was observed in forward-biased $p-n$ junction diodes an- 


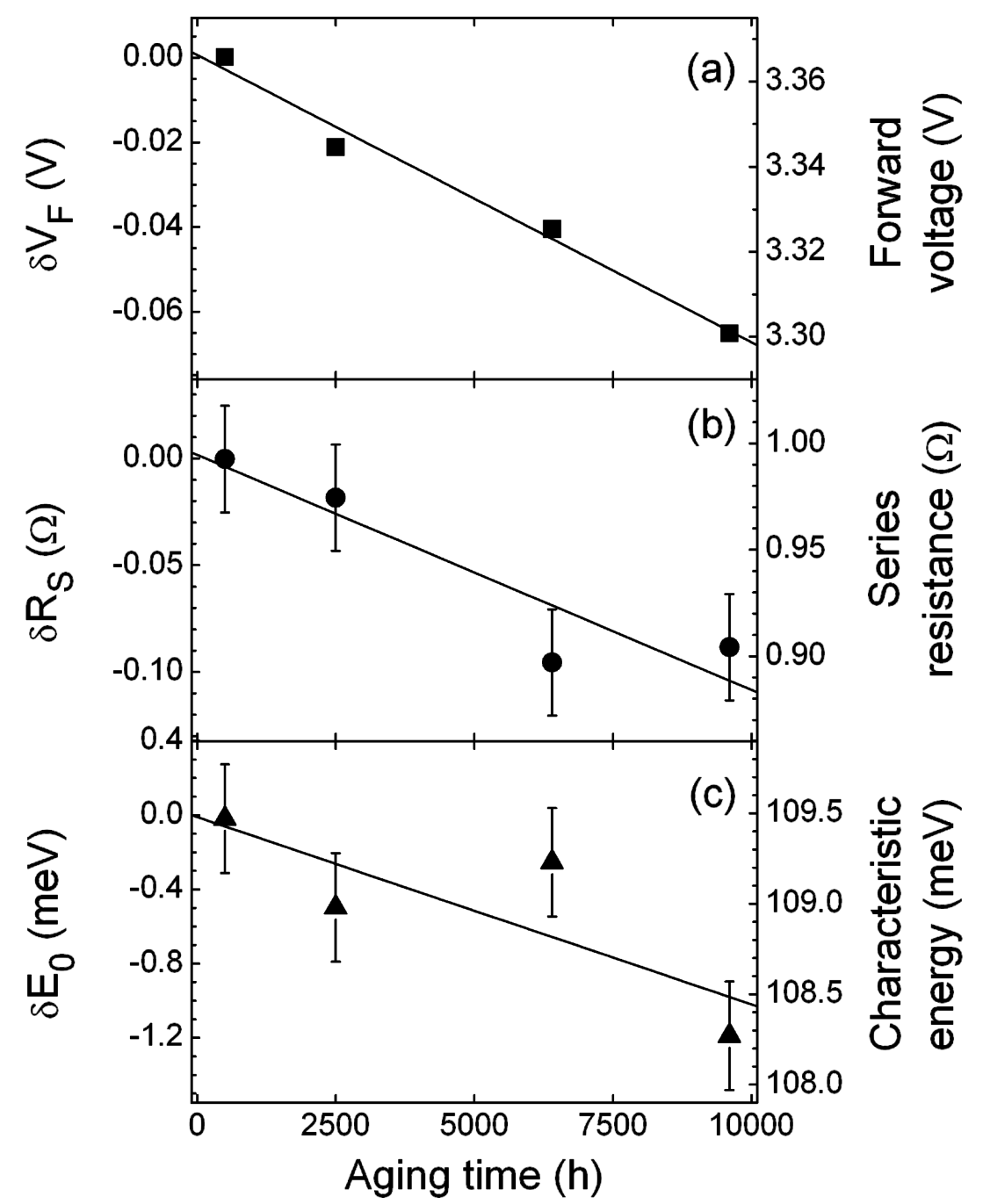

Fig. 2. Average variation of the electrical parameters of four high-power InGaN LEDs with time: (a) forward voltage at nominal current, (b) series resistance, (c) characteristic energy of the injection process.

nealed at about $450 \mathrm{~K}$ for $\sim 1$ hour. Under assumption of an exponential probability of dissociation with the activation energy of about $1 \mathrm{eV}$, one can expect a similar annealing effect at $350 \mathrm{~K}$ on the 1000-hour scale. Therefore, we attribute the observed long-term decrease in series resistance of InGaN LEDs to the self-annealing of residual $\mathrm{Mg}-\mathrm{H}$ complexes facilitated by the common leakage of electrons into the $p$ cladding layer at nominal driving currents [20]. Such an increase in the concentration of ionized acceptors might be revealed by the capacitance-voltage $(C-V)$ method [25]. Unfortunately, in our case it was too small to invoke a variation of the charge profile in the $p$ cladding layer beyond the experimental uncertainty.

The increase in junction conductivity probably has a more complex origin due to both variation of the density of ionized acceptors in the $p$ cladding layer and the density and spectrum of localized states in the active layers.

\section{Conclusion}

We observed a long-term decrease of the forward voltage in high-power InGaN LEDs and applied an analytical approach for $I-V$ characteristics that revealed the variation of series resistance and junction conductivity with aging time. The decrease of series resistance was attributed to slow post-fabrication self-annealing of the $p$-type cladding layer facilitated by the presence of minority carriers.

\section{Acknowledgement}

This work was supported by the Lithuanian State Science and Studies Foundation. 


\section{References}

[1] M.S. Shur and A. Žukauskas, Solid-state lighting: Toward superior illumination, Proc. IEEE 93(10), 16911703 (2005).

[2] T. Egawa, H. Ishikawa, T. Jimbo, and M. Umeno, Optical degradation of InGaN/ AlGaN light-emitting diode on sapphire substrate grown by metalorganic chemical vapor deposition, Appl. Phys. Lett. 69(6), 830-833 (1996).

[3] T. Yanagisawa, Estimation of the degradation of InGaN / AlGaN blue light-emitting diodes, Microelectron. Reliab. 37(8), 1239-1241 (1997).

[4] N. Narendran, Y. Gu, J.P. Freyssinier, H. Yu, and L. Deng, Solid-state lighting: Failure analysis of white LEDs, J. Cryst. Growth 268(3-4), 449-456 (2004).

[5] Z. Gong, M. Gaevski, V. Adivarahan, W. Sun, M. Shatalov, and M. Asif Khan, Optical power degradation mechanisms in AlGaN-based $280 \mathrm{~nm}$ deep ultraviolet light-emitting diodes on sapphire, Appl. Phys. Lett. 88(12), 121106-1-3 (2006).

[6] T. Egawa, T. Jimbo, and M. Umeno, Characteristics of InGaN / AlGaN light-emitting diodes on sapphire substrates, J. Appl. Phys. 82(11), 5816-5821 (1997).

[7] M. Osiński, D.L. Barton, P. Perlin, and J. Lee, Effects of high electrical stress on $\mathrm{GaN} / \mathrm{InGaN} / \mathrm{AlGaN}$ singlequantum-well light-emitting diodes, J. Cryst. Growth 189-190, 808-811 (1998).

[8] O. Pursiainen, N. Linder, A. Jaeger, R. Oberschmid, and K. Streubel, Identification of aging mechanisms in the optical and electrical characteristics of lightemitting diodes, Appl. Phys. Lett. 79(18), 2895-2897 (2001).

[9] T. Yanagisawa and T. Kojima, Degradation of InGaN blue light-emitting diodes under continuous and lowspeed operations, Microelectron. Reliab. 43(6), 977980 (2003).

[10] M. Meneghini, S. Podda, A. Morelli, R. Pintus, L. Trevisanello, G. Meneghesso, M. Vanzi, and E. Zanoni, High brightness GaN LEDs degradation during dc and pulsed stress, Microelectron. Reliab. 46(9-11), 17201724 (2006).

[11] M. Osiński, J. Zeller, P.-C. Chiu, B.S. Phillips, and D.L. Barton, AlGaN/InGaN/ GaN blue light emitting diode degradation under pulsed current stress, Appl. Phys. Lett. 69(7), 898-900 (1996).

[12] J.J. Wierer, D.A. Steigerwald, M.R. Krames, J.J. O'Shea, M.J. Ludowise, G. Christenson, Y.-C. Shen, C. Lowery, P.S. Martin, S. Subramanya, W. Götz, N.F. Gardner, R.S. Kern, and S.A. Stockman, High power AlGaInN flip-chip light-emitting diodes. Appl. Phys. Lett. 78(22), 3379-3381 (2001).

[13] Technical Datasheet DS23, http://www.lumileds.com/ pdfs/ds23.pdf.

[14] Z. Vaitonis, P. Vitta, and A. Žukauskas, Measurement of the junction temperature in high-power light- emitting diodes from high-energy wing of the electroluminescence band, J. Appl. Phys. 103(9), 093110-1-7 (2008).

[15] LED Lifetime for General Lighting, ASSIST Recommends 1(1) (Lighting Research Center, 2005), http://www.lrc.rpi.edu/ .

[16] Y. Xi, J.-Q. Xi, T. Gessmann, J.M. Shah, J.K. Kim, E.F. Schubert, A.J. Fischer, M.H. Crawford, K.H.A. Bogart, and A.A. Allerman, Junction and carrier temperature measurements in deep-ultraviolet light-emitting diodes using three different methods, Appl. Phys. Lett. 86(3), 031907-1-3 (2005).

[17] H.C. Casey, Jr., J. Muth, S. Krishnankutty, and J.M. Zavada, Dominance of tunneling current and band filling in InGaN/ AlGaN double heterostructure blue lightemitting diodes, Appl. Phys. Lett. 68(20), 2867-2869 (1996).

[18] P. Perlin, M. Osiński, P.G. Eliseev, V.A. Smagley, J. Mu, M. Banas, and P. Sartori, Low-temperature study of current and electroluminescence in InGaN/AlGaN/GaN double-heterostructure blue light-emitting diodes, Appl. Phys. Lett. 69(12), 1680-1682 (1996).

[19] A. Žukauskas, M.S. Shur, and R. Gaska, Introduction to Solid-State Lighting (Wiley, New York, 2002).

[20] E.F. Schubert, Light-Emitting Diodes (Cambridge University Press, Cambridge, 2006).

[21] A.Y. Polyakov, N.B. Smirnov, A.V. Govorkov, J. Kim, B. Luo, R. Mehandru, F. Ren, K.P. Lee, S.J. Pearton, A.V. Osinsky, and P.E. Norris, Enhanced tunneling in $\mathrm{GaN} / \mathrm{InGaN}$ multi-quantum-well heterojunction diodes after short-term injection annealing, J. Appl. Phys. 91(8), 5203-5207 (2002).

[22] F. Manyakhin, A. Kovalev, and A.E. Yunovich, Aging mechanisms of InGaN/AlGaN/GaN light-emitting diodes operating at high currents, MRS Internet J. Nitride Semicond. Res. 3, art. no. 53 (1998).

[23] M. Pavesi, M. Manfredi, G. Salviati, N. Armani, F. Rossi, G. Meneghesso, S. Levada, E. Zanoni, S.Du, and I. Eliashevich, Optical evidence of an electrothermal degradation of InGaN-based light-emitting diodes during electrical stress, Appl. Phys. Lett. 84(17), 34033405 (2004).

[24] S. Nakamura, N. Iwasa, M. Senoh, and T. Mukai, Hole compensation mechanism of $p$-type GaN, Jpn. J. Appl. Phys. 31(5A), 1258-1266 (1992).

[25] S.J. Pearton, J.W. Lee, and C. Yuan, Minority-carrierenhanced reactivation of hydrogen-passivated $\mathrm{Mg}$ in GaN, Appl. Phys. Lett. 68(19), 2690-2692 (1996).

[26] M. Miyachi, T. Tanaka, Y. Kimura, and H. Ota, The activation of $\mathrm{Mg}$ in $\mathrm{GaN}$ by annealing with minoritycarrier injection, Appl. Phys. Lett. 72(9), 1101-1103 (1998). 


\title{
SENĖJIMO İTAKA DIDELĖS GALIOS InGaN ŠVIESOS DIODŲ NUOSEKLIAJAI VARŽAI IR SANDŪROS LAIDUMUI
}

\author{
Z. Vaitonis, A. Miasojedovas, A. Novičkovas, S. Sakalauskas, A. Žukauskas
}

Vilniaus universiteto Medžiagotyros ir taikomuju mokslu institutas

\section{Santrauka}

Tirti didelès galios šviesos diodų tiesioginès įtampos, nuosekliosios varžos bei sandūros laidumo pokyčiai vykstant senèjimo procesui. Po $\sim 9600$ valandų sendinimo normaliomis darbo sąlygomis (tiesioginè srovė $350 \mathrm{~mA}$, sandūros temperatūra apie $350 \mathrm{~K}$ ), nusta- tytas dèsningas, $-1 \% / 1000$ val., nuosekliosios varžos mažejimas ir $-0.1 \% / 1000$ val. tunelinès injekcijos i aktyviają sritį charakteringos energijos mažèjimas. Pastebèti kitimai gali būti susiję su savaiminiu diodo $p$ sluoksnio atkaitinimu ir lokalizuotųjų būsenų tankio kitimu aktyviojoje srityje. 